\title{
Variability Studies for Seed Morphological Traits in Safflower Genotypes
}

\author{
Kartoori Saisanthosh $^{1 *}$, K. Keshavulu ${ }^{\text {* }}$, T. Joesph Raju ${ }^{1}$, \\ Kadirvel Palchamy ${ }^{2}$, N. Mukta ${ }^{2}$ and Razia Sultana ${ }^{1}$ \\ ${ }^{1}$ Department of Seed Science and Technology, College of Agriculture, PJTSAU, \\ Hyderabad-30, Telangana, India \\ ${ }^{2}$ ICAR-Indian Institute of Oilseeds Research, Rajendranagar, Hyderabad-30, \\ Telangana, India \\ *Corresponding author
}

\section{A B S T R A C T}

\begin{tabular}{l} 
Ke y w or d s \\
$\begin{array}{l}\text { Safflower (Carthamus } \\
\text { tinctorius L.), Genotypes, } \\
\text { Safflower }\end{array}$ \\
Article Info \\
$\begin{array}{l}\text { Accepted: } \\
\text { 18 September } 2018 \\
\text { Available Online: } \\
\text { 10 October } 2018\end{array}$ \\
\hline
\end{tabular}

\section{Keywords}

Safflower (Carthamus

\section{Introduction}

Safflower (Carthamus tinctorius L.) is a member of Asteraceae family originated in the region spanning India, Afghanistan and Ethiopia. It is mentioned as kusumba in ancient Indian scriptures but is known as kusube in Kannada, kardai in Marathi and kusum in Hindi. The cultivated safflower is a diploid with 24 chromosomes. Safflower is one of the oldest multipurpose oilseed crops in the world. Traditionally, it is grown for its seeds, flowers, fabric dyes, food colouring and for medicinal reasons (Li and Mundel, 1996). The natural dyes called carthamin is extracted from brilliantly coloured flowers. The seeds are used for extraction of vegetable oil for consumption as well as industrial uses.

The oil is one of the best cooking oils due to its high level of unsaturated fatty acid content (>75\% linoleic or oleic acid). India, China, Mexico, USA, Ethiopia, Argentina and Australia are major growing safflower countries in the world. China mostly grows safflower for medicinal uses. Transgenic safflower has also been developed to produce human insulin from seeds, which provides a cheaper option for meeting the global demand for human insulin (Boothe et al., 2010). 
During the last decade, the global area under safflower cultivation ranged from 0.70 to 0.98 million ha and the production ranged from 0.53 to 0.83 million tonnes. India accounted for $>30 \%$ (0.23 million ha) of area and $>20$ per cent (0.15 million tonnes) of global production (FAOSTAT, 2012).In India, safflower occupies seventh place among oilseed crops viz., groundnut, rapeseed and mustard, soybean, castor, sunflower, linseed, sesame and niger. It is grown over 3 lakh ha with a production of about 1.89 lakh tonnes and the productivity of about $630 \mathrm{~kg} / \mathrm{ha}$ (FAOSTAT, 2012). Maharashtra, Karnataka and Andhra Pradesh are the major safflower growing states in India. All India Coordinated Research Programme was started in the 1990s to improve safflower productivity in the country.

These studies clearly demonstrate that a detailed understanding on the relationships among various seed morphological traits would help to identify a combination of traits that could be used in crop improvement programme for selecting plants with better seed traits without compromising other desirable agronomic attributes. However, the morphological traits are highly influenced by the environments, which is a major limitation of using these correlated traits in plant selections.

\section{Materials and Methods}

The details of the material used and methodologies adopted in the present study are presented below.

\section{Materials}

Sixty one genotypes including elite germplasm lines and check varieties were used for the study. The pure seeds of all these genotypes were collected from ICRISAT farm of IIOR, Hyderabad.

\section{Methodology}

The field experiment was conducted at the research farms of ICAR-IIOR (at Rajendranagar and ICRISAT), Hyderabad during October to February, 2014-15. The experiment was laid out in Augmented Randomized Block Design (Augmented RCB) in three blocks with four checks. Each block consisted of 19 genotypes along with checks and spacing of $45 \mathrm{~cm} \times 20 \mathrm{~cm}$ and row length of $2 \mathrm{~m}$ were adopted for the study.

The farms are geographically situated at an altitude of $545 \mathrm{~m}$ above mean sea level and located at $17^{\circ} 51^{\prime} \mathrm{N}$ latitude and $78^{\circ} 27^{\prime} \mathrm{E}$ longitude and falls under the Southern Telangana agro-climatic zone of Telangana State. All the recommended practices and plant protection measures were adopted for raising healthy crop. The laboratory work was carried out at seed quality testing laboratory of Department of Seed Science and Technology, College of Agriculture, Rajendranagar, Hyderabad.

\section{Observations recorded}

The seeds were dried, cleaned graded for uniform size and used to assess the following seed quality attributes at Department of Seed Science and Technology, College of Agriculture, PJTSAU, Rajendranagar, Hyderabad.

\section{Moisture content (\%)}

Five grams of seed samples was taken at random from each of the genotype in three replications for moisture estimation. Moisture content of the seed sample was determined by quantitative/gravimetric method by using low constant temperature oven method as per ISTA rules. The seeds were dried in oven at $103 \pm 1$ for $17 \mathrm{~h}$, cooled in a desiccator over silica gel. The samples were weighed and the 
seed moisture content was calculated and expressed in percentage on wet weight basis by using following formula

Moisture content $(\%)=\frac{\mathrm{W}_{2}-\mathrm{W}_{3}}{----------}$ x 100

$\mathrm{W} 1=$ Weight of metal dish and its lid (g)

W2 = Weight of metal dish, its lid and seed before drying $(\mathrm{g})$

W3 = Weight of metal dish, its lid and seed after drying $(\mathrm{g})$

\section{Seed size (mm)}

A total of 30 seeds were randomly selected from each genotypes and grouped in three replications of 10 seeds each and seed size was measured by digital grain vernier meter. The average value was expressed in milli meters.

\section{Test weight (g)}

One hundred of eight replicates were counted randomly in each replication and average weight was recorded on a top pan balance with an accuracy of $0.001 \mathrm{~g}$ and expressed in grams.

\section{Hull type}

Various types of seed hull have been reported in safflower, which include normal, striped, thin, reduced and partial ( $\mathrm{Li}$ and Mundel 1996) the genotypes set used in this study consisted only of two hull types like normal and striped, which were scored usually as 0 and 1 respectively.

\section{Hull content (\%)}

The percentage of the fraction of hulls was calculated as the ratio of the seed hull to the total seed. Hundred seeds per seed sample per replication were dried $\left(5 \mathrm{~h}\right.$ at $\left.60^{\circ} \mathrm{C}\right)$, weighed and afterwards watered for $15 \mathrm{~h}$. The seed hulls were separated from the rest and dried (5 $\mathrm{h}$ at $60^{\circ} \mathrm{C}$ ). Then weighed and per cent of whole seed weight calculated (Rudolphi et al., 2012)

\section{Seed colour}

Seeds of each germplasm accessions were observed for colour variation and classified into white, cream and brown. Qualitative scores 1, 2 and 3 were assigned to white, cream and brown respectively.

\section{Bulk density $\left(\mathrm{tm}^{-3}\right)$}

Seed density is the ratio of mass sample of safflower to its total volume. It was determined by filling a $1000 \mathrm{ml}$ container with seeds from a height of about $15 \mathrm{~cm}$, striking the top level and then weighing the content (Deshpande, 1993).

\section{Results and Discussion}

\section{Seed morphological traits}

Mean and range of seed morphological traits like seed size (seed length, breadth, thickness, length breadth ratio and length breadth product), hull content, test weight and bulk density in a set of 57 safflower genotypes are presented in Table 1.

Among checks, the variety A1 had the largest seed size as reflected by larger seed length $(9.20 \mathrm{~mm})$, breadth $(4.35 \mathrm{~mm})$, thickness $(3.92$ $\mathrm{mm}$ ), length breadth ratio (2.11) and length breadth product (40.12) and length breadth thickness product $\left(157.42 \mathrm{~mm}^{3}\right)$ followed by Bhima (135.00 $\left.\mathrm{mm}^{3}\right)$ and NARI-57 (123.83 $\left.\mathrm{mm}^{3}\right)$. Centennial had the lowest seed size compared to rest of the check varieties (79.81 $\mathrm{mm}^{3}$ ) Plate 1 . The genotypes set exhibited 
substantial variation for seed size (Table 1) with the range of traits that exceeded the check values.

\section{Seed size $(\mathbf{m m})$}

Seed size varied among the genotypes (Table 1). Among checks, A1 had the highest length breadth thickness product $\left(157.42 \mathrm{~mm}^{3}\right)$ followed by Bhima $\left(135 \mathrm{~mm}^{3}\right)$ and NARI-57 $\left(123.83 \mathrm{~mm}^{3}\right)$. Centennial had the lowest of 79.81. Length breadth thickness product ranged from $43.54-174.00 \mathrm{~mm}^{3}$ with the mean of $102.43 \mathrm{~mm}^{3}$ in the genotypes set. EC-19 had the highest length breadth thickness product of $174.22 \mathrm{~mm}^{3}$ and EC-15 had the lowest of $43.54 \mathrm{~mm}^{3}$. Reduction in seed size might be due to higher temperatures during reproductive growth stage and shortened time for seed to develop fully before maturity. Moreover, high temperature stress during reproductive development may negatively affect cell expansion, cotyledon cell number and thus, seed filling rate, resulting in reduced seed size. Seeds have a highly regulated capacity to achieve a uniform size but high temperature stress imposed during the midreproductive stage prevented seed filling capacity to the full potential size (Duthion and Pigeaire, 1991). The results are in consistent with Rahim et al., (2014) who reported the variation of seed morphological traits such as seed length $(6.51 \mathrm{~mm}$ to $7.49 \mathrm{~mm})$, seed wideness $(3.78 \mathrm{~mm}$ to $4.33 \mathrm{~mm}$ ) and seed thickness (3.14 $\mathrm{mm}$ to $3.63 \mathrm{~mm}$ ) among 10 safflower varieties grown in Turkey. In the present study, the genotypes EC-9, EC-17, EC-19, EC-20, EC-23, GMU-7 and GMU-8 showed promising for larger seed size compared to the check A1. Whereas EC-15 and GMU-2 genotypes were promising for smaller seed size. Further, in general the genotypes with higher seed weight possess high germination and vigorous seedlings. However, due to variation in seed size, imbibitions might have obstructed and thus a clear-cut relationship between the morphological, physiological and biochemical seed quality attributes could not be established (Olasoji et al., 2011)

\section{Test weight (g)}

Significant variance was found among safflower genotypes for test weight (Table 1). Among checks, A1 had the highest test weight $(6.68 \mathrm{~g})$ followed by Bhima $(5.77 \mathrm{~g})$ and NARI-57 (3.96 g). The variety Centennial had the test weight of $3.11 \mathrm{~g}$. The test weight ranged from $2.17 \mathrm{~g}$ (EC-15) to $5.71 \mathrm{~g}$ (GMU12) with the mean of $4.18 \mathrm{~g}$. None of the genotypes tested in this study had higher test weight than the check A1 (6.68 g). FernandezMartinez et al., (1993) reported that 100-seed weight in a collection of 200 safflower accessions ranged from $2.1 \mathrm{~g}$ to $5.4 \mathrm{~g}$ in Spain. Rahim et al., (2014) reported that test weight varied from $3.18 \mathrm{~g}$ to $4.15 \mathrm{~g}$ among 10 safflower varieties grown in Turkey.

Test weight is an important seed quality parameter, which basically indicates the seed density. High test weight in the seed occurs due to increased density which may be contributed by decrease in airspace within the hull, decrease in kernel oil and increase in hull content. Through cytological experiments, Li et al., (2015) reported that cell number is the major contributor for the genetic variation for seed weight in rapeseed. Test weight has been used as a selection technique for improving oil content in oilseed crops; high density seeds (high test weight) had low oil content and vice versa (Hartwig and Collins 1962).

\section{Hull type}

In this study, two types of hulls were observed on seeds namely normal and striped. The numbers of genotypes with normal and striped hulls were 41 and 20, respectively including checks (Table 1). Normal hulls are made up of 
different layers of tissues such as the epidermis, hypodermis, outer schlerenchyma, phytomelanin layer, inner schlerenchyma, outer epidermis of the seed coat, the parenchymous layer of the seed coat, inner epidermis of the seed coat, and the endosperm. Various types of hull mutants - striped, greystriped, partial, reduced and thin have been described in safflower (Ebert and Knowles 1968; Abel and Lorance, 1976, Urie 1986). Lockwood (1966) studied the seed anatomical features leading to various hull types in safflower.

The mutant hull types differ from the normalhull in the degree of thickness, localization of thickness, lignification and compression of the sclerenchyma layers of the pericarp. They also differed in the absence and localization of the phytomelanin layer, the color of the outer epidermis of the integument, and the degree of thickness of the parenchymous layer of the integument.

In thin hull types, a high degree of compression takes place in the outer sclerenchyma and the character do hot become evident until about 10 days after fertilization when the outer sclerenchyma fails to lignify as it normally would. In the brown striped hull types, the phytomelanin layer will be localized in definite canals rather than being continuous as in the normal-hull achene. Lignification of the cells in the pericarp also is restricted to the regions' above and below these canals and the pericarp is generally not as thick as in the normal-hull.

In appearance the achenes are more elongated than the normal-hull achenes and are white with vertical brown stripes usually running the length of the achene. The grey striped-hull type differs from the normal hull in the greystriped appearance of the achene and in the degree of thickness of its pericarp. In this type, both the outer and inner sclerenchyma layers appear thin. These thin layers extend vertically the length of the achene, vary in width and may be visible as only a thin grey stripe. Anatomically these thin areas resemble the pericarp of the achenes showing the thin-hull type but these areas in the grey striped-hull type may show even more compression. In the thinnest areas, the inner and outer sclerenchyma layers are almost non-existent. In combination with the thin-hull type, the pericarp is thin but not uniformly, which gives the achene a grey color with very faint vertical lines.

Ebert and Knowles (1968) reported that reduced development of fibrous tissues in the seed coat resulted in thin hull types in safflower. The normal hulled seeds had well developed fibres of the vascular bundles on the seed coat whereas thin hulled seeds had reduced development of fibres on the vascular bundles. Hulls of the mutant strains were thin because cells were not sclerified during differentiation of the pericarp. Striped hulls resulted from the additional localisation of secretary canals in the pericarp.

\section{Hull content (\%)}

Significant variation among safflower genotypes was observed for hull content (Table 1). Among checks, the variety A1 had the highest hull content (52.24\%) followed by Bhima (42.39\%) and NARI-57 (35.20\%), whereas the variety Centennial had the lowest hull content (31.37\%). Hull content ranged from $29.50 \%$ (EC-7) to $62.43 \%$ (EC-13) in the genotypes set. Applewhite (1966) reported that many of the safflower varieties had hull content of about $40 \%$ though varieties with $59-78 \%$ hull existed. Rahim et al., (2014) also reported that the hull ratio of safflower varieties grown in Turkey ranged from $42 \%$ to $55 \%$. Many of the released safflower varieties in India possess high hull content (Mukta et al., 2012). 


\section{Int.J.Curr.Microbiol.App.Sci (2018) 7(10): 2204-2216}

Table.1 Mean performance of seed physical traits in a set of 57 safflower genotypes compared with four check varieties

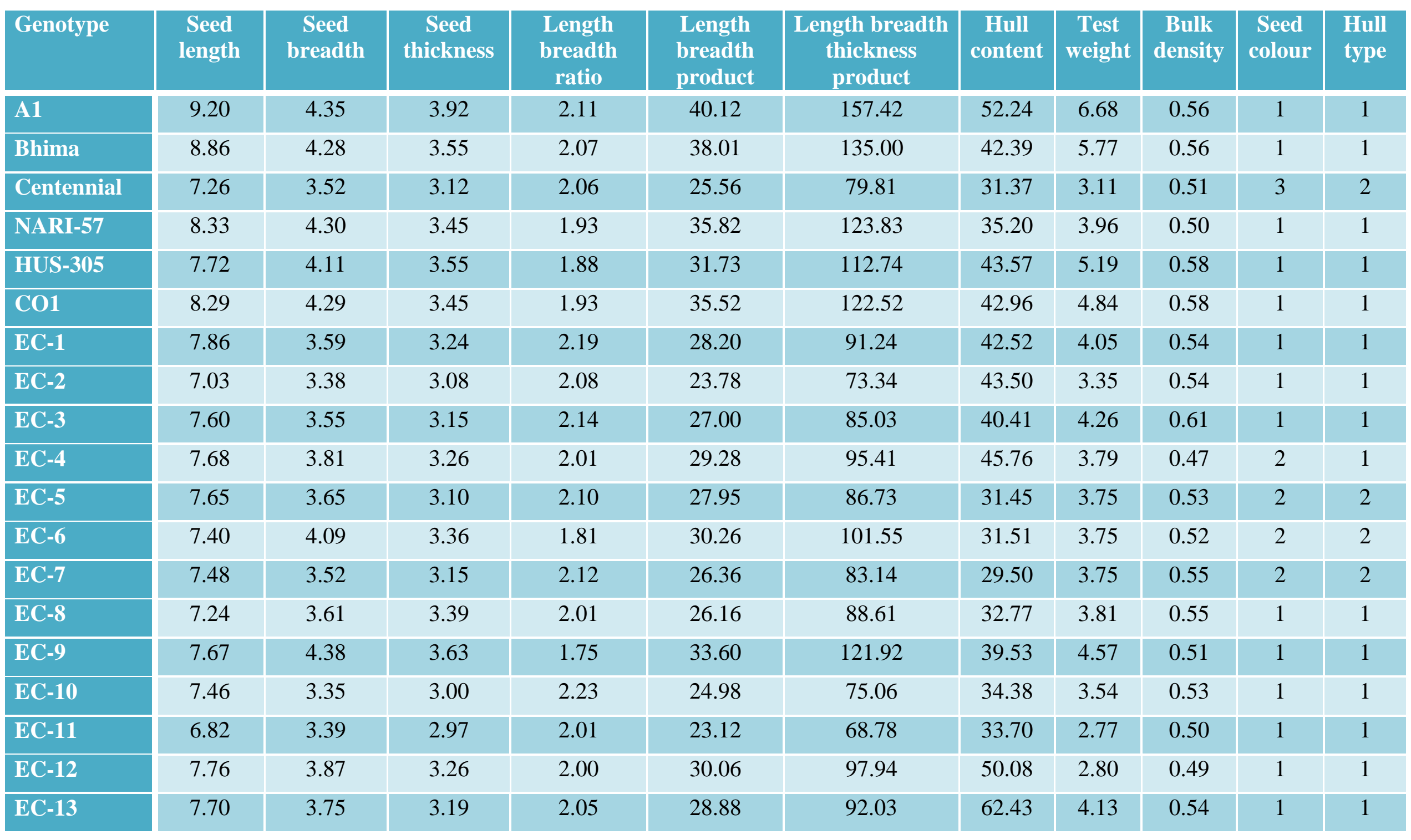


Int.J.Curr.Microbiol.App.Sci (2018) 7(10): 2204-2216

\begin{tabular}{|c|c|c|c|c|c|c|c|c|c|c|c|}
\hline EC-14 & 7.38 & 3.41 & 2.76 & 2.17 & 25.14 & 69.40 & 35.42 & 2.83 & 0.56 & 2 & 2 \\
\hline EC-15 & 6.33 & 2.72 & 2.52 & 2.33 & 17.24 & 43.54 & 30.66 & 2.17 & 0.46 & 3 & 2 \\
\hline EC-16 & 8.92 & 3.64 & 3.37 & 2.45 & 32.48 & 109.35 & 46.30 & 4.02 & 0.55 & 2 & 2 \\
\hline EC-17 & 8.22 & 3.49 & 3.08 & 2.35 & 28.70 & 88.31 & 43.33 & 3.74 & 0.58 & 1 & 1 \\
\hline EC-18 & 7.57 & 3.32 & 2.93 & 2.28 & 25.08 & 73.49 & 35.12 & 3.14 & 0.46 & 2 & 2 \\
\hline EC-19 & 9.28 & 4.42 & 4.24 & 2.10 & 41.60 & 174.22 & 38.62 & 5.07 & 0.52 & 2 & 2 \\
\hline EC-20 & 8.19 & 3.46 & 3.15 & 2.37 & 28.34 & 89.13 & 33.01 & 4.28 & 0.51 & 2 & 2 \\
\hline EC-21 & 8.19 & 3.76 & 3.31 & 2.18 & 30.78 & 101.78 & 34.06 & 3.49 & 0.56 & 2 & 2 \\
\hline EC-22 & 8.26 & 3.58 & 2.97 & 2.31 & 29.52 & 87.56 & 36.31 & 4.05 & 0.51 & 2 & 2 \\
\hline EC-23 & 8.12 & 3.88 & 3.59 & 2.09 & 31.46 & 113.06 & 43.07 & 4.44 & 0.52 & 1 & 1 \\
\hline EC-24 & 7.51 & 3.67 & 3.20 & 2.05 & 27.55 & 88.27 & 33.19 & 3.99 & 0.53 & 2 & 2 \\
\hline EC-25 & 7.95 & 3.57 & 3.13 & 2.23 & 28.38 & 88.73 & 34.06 & 3.52 & 0.50 & 2 & 2 \\
\hline EC-26 & 7.53 & 4.07 & 3.50 & 1.85 & 30.62 & 107.32 & 35.25 & 3.58 & 0.50 & 1 & 1 \\
\hline EC-27 & 8.08 & 3.47 & 3.12 & 2.33 & 28.04 & 87.37 & 53.88 & 3.05 & 0.40 & 1 & 1 \\
\hline EC-28 & 7.72 & 3.81 & 3.28 & 2.03 & 29.40 & 96.31 & 56.72 & 4.30 & 0.50 & 1 & 1 \\
\hline EC-29 & 7.69 & 3.58 & 3.12 & 2.15 & 27.55 & 86.06 & 40.51 & 3.96 & 0.61 & 1 & 1 \\
\hline EC-30 & 7.33 & 3.30 & 3.11 & 2.22 & 24.16 & 75.03 & 41.62 & 3.81 & 0.54 & 1 & 1 \\
\hline EC-31 & 7.59 & 3.62 & 3.36 & 2.10 & 27.45 & 92.18 & 35.32 & 4.16 & 0.59 & 2 & 1 \\
\hline EC-32 & 8.42 & 4.08 & 3.68 & 2.06 & 34.36 & 126.57 & 31.64 & 2.68 & 0.48 & 1 & 1 \\
\hline EC-33 & 7.54 & 3.64 & 3.40 & 2.07 & 27.42 & 93.23 & 33.31 & 3.40 & 0.54 & 1 & 1 \\
\hline EC-34 & 8.06 & 3.74 & 3.33 & 2.15 & 30.19 & 100.39 & 33.32 & 3.84 & 0.52 & 1 & 2 \\
\hline EC-35 & 7.83 & 3.69 & 3.16 & 2.12 & 28.88 & 91.24 & 40.20 & 2.93 & 0.40 & 2 & 2 \\
\hline EC-36 & 7.67 & 3.35 & 2.97 & 2.29 & 25.71 & 76.36 & 36.17 & 3.53 & 0.54 & 2 & 2 \\
\hline
\end{tabular}


Int.J.Curr.Microbiol.App.Sci (2018) 7(10): 2204-2216

\begin{tabular}{|c|c|c|c|c|c|c|c|c|c|c|c|}
\hline GMU-1 & 8.32 & 4.00 & 3.41 & 2.08 & 33.29 & 113.46 & 41.07 & 4.21 & 0.55 & 2 & 1 \\
\hline GMU-2 & 6.67 & 4.07 & 3.72 & 1.64 & 27.13 & 100.86 & 40.25 & 4.85 & 0.60 & 1 & 1 \\
\hline GMU-3 & 7.39 & 3.71 & 3.27 & 2.00 & 27.40 & 89.55 & 51.29 & 3.96 & 0.53 & 1 & 1 \\
\hline GMU-4 & 8.98 & 3.67 & 3.25 & 2.45 & 32.98 & 107.17 & 41.30 & 4.54 & 0.54 & 2 & 2 \\
\hline GMU-5 & 8.11 & 4.33 & 3.67 & 1.87 & 35.13 & 128.98 & 39.46 & 5.07 & 0.59 & 1 & 1 \\
\hline GMU-6 & 7.54 & 4.16 & 3.54 & 1.81 & 31.35 & 111.07 & 44.75 & 5.16 & 0.64 & 1 & 1 \\
\hline GMU-7 & 8.43 & 4.38 & 3.77 & 1.92 & 36.90 & 139.17 & 47.10 & 5.10 & 0.60 & 1 & 1 \\
\hline GMU-8 & 9.25 & 4.27 & 3.51 & 2.17 & 39.46 & 138.40 & 44.92 & 5.21 & 0.58 & 2 & 2 \\
\hline GMU-9 & 7.35 & 4.24 & 3.63 & 1.73 & 31.19 & 113.19 & 42.76 & 3.31 & 0.46 & 2 & 2 \\
\hline GMU-10 & 7.44 & 3.72 & 3.46 & 2.00 & 27.70 & 95.94 & 39.71 & 4.70 & 0.58 & 1 & 1 \\
\hline GMU-11 & 8.78 & 3.58 & 3.47 & 2.45 & 31.42 & 108.93 & 43.51 & 4.64 & 0.47 & 1 & 1 \\
\hline GMU-12 & 7.88 & 4.20 & 3.40 & 1.87 & 33.10 & 112.39 & 45.57 & 5.71 & 0.61 & 1 & 1 \\
\hline GMU-13 & 7.47 & 4.17 & 3.38 & 1.79 & 31.15 & 105.40 & 38.45 & 5.34 & 0.58 & 1 & 1 \\
\hline GMU-14 & 7.36 & 3.67 & 3.27 & 2.01 & 27.02 & 88.39 & 45.01 & 4.06 & 0.52 & 1 & 1 \\
\hline GMU-15 & 7.39 & 4.28 & 3.41 & 1.72 & 31.64 & 107.9 & 47.73 & 4.57 & 0.60 & 1 & 1 \\
\hline GMU-16 & 7.42 & 3.80 & 3.34 & 1.95 & 28.21 & 94.18 & 34.43 & 3.93 & 0.57 & 1 & 1 \\
\hline GMU-17 & 7.38 & 3.56 & 3.41 & 2.07 & 26.32 & 89.66 & 49.95 & 4.68 & 0.62 & 1 & 1 \\
\hline GMU-18 & 7.80 & 3.63 & 3.24 & 2.15 & 28.30 & 91.60 & 45.97 & 4.28 & 0.55 & 1 & 1 \\
\hline GMU-19 & 6.64 & 3.74 & 3.57 & 1.78 & 24.82 & 88.65 & 44.64 & 4.55 & 0.60 & 1 & 1 \\
\hline Mean & 7.87 & 3.83 & 3.35 & 2.07 & 30.28 & 102.43 & 40.53 & 4.18 & 0.54 & - & - \\
\hline Range & $\begin{array}{c}6.33- \\
9.28\end{array}$ & $2.72-4.42$ & $2.76-4.24$ & $1.64-2.45$ & $17.24-41.60$ & $43.54-174.00$ & $\begin{array}{c}29.50- \\
62.43\end{array}$ & $\begin{array}{c}2.17- \\
5.71\end{array}$ & $\begin{array}{c}0.40- \\
0.64\end{array}$ & - & - \\
\hline SD & 0.67 & 0.37 & 0.29 & 0.18 & 4.84 & 24.18 & 7.62 & 0.97 & 0.05 & - & - \\
\hline
\end{tabular}


Plate.1 Variability for seed morphological traits in safflower genotypes

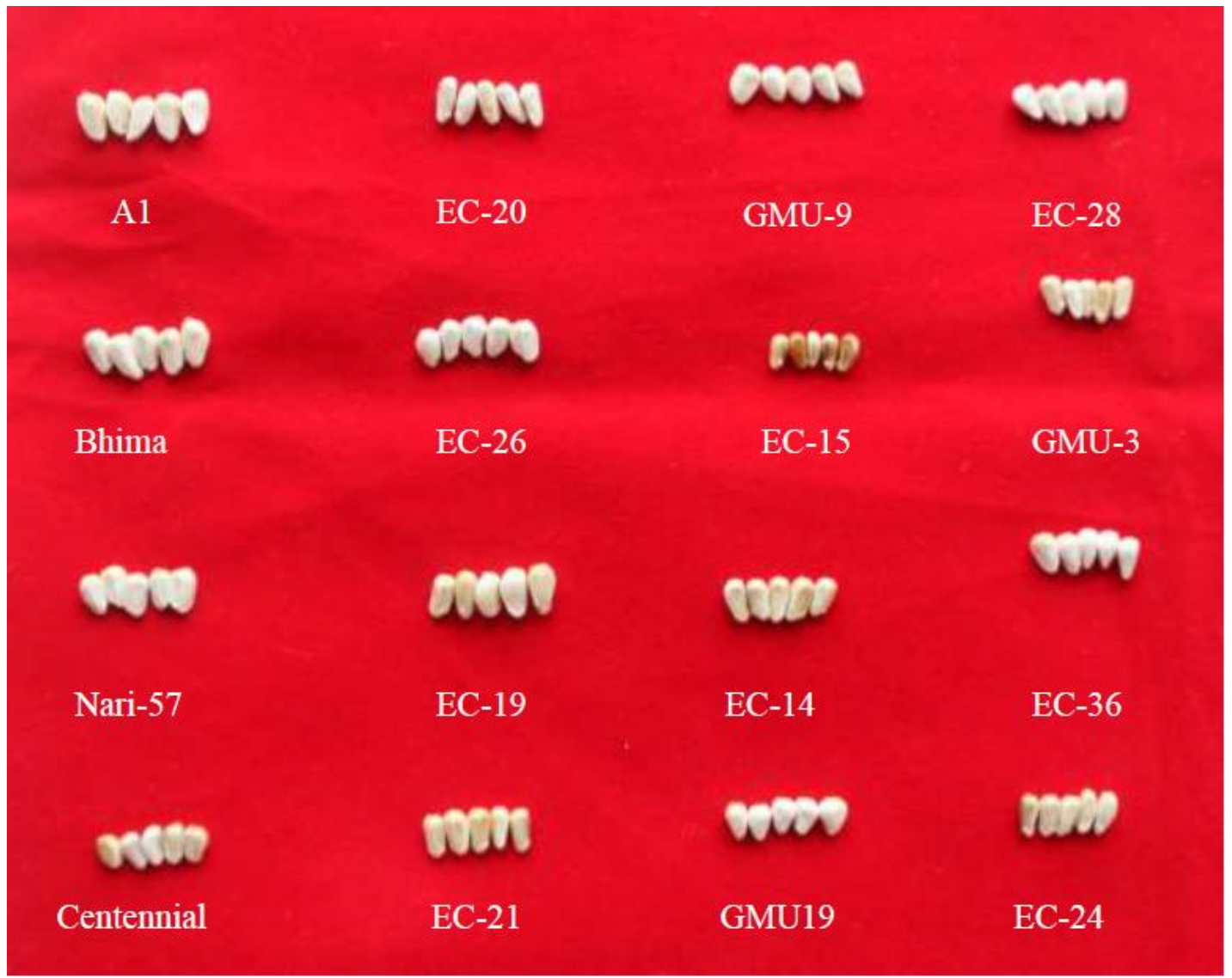

A possible reason for the variation in hull percentage in the genotypes set studied could be due to variation in hull types and thickness. The safflower seed is composed of hull and kernel. The hull proportion is about 32 to $65 \%$ and contains $1-2 \%$ oil, in general (Classen et al., 1950). Different hull types have been identified in safflower based on the development of the inner and outer schlerenchyma cells; normal-hull, partial hull, thin-hull and striped hull (Ebert and Knowles (1968), Urie and Zimmerman, (1970). Major portion $(60 \%)$ of the hull in the normal-hull is composed of the highly lignified inner and outer schlerenchymas. Variations in the development of schlerenchymas contribute to variation in hull content (Ebert and Knowles 1966). The hull content is also influenced by the genotype, environment and the seed's position on the plant, i.e. seeds from primary or secondary capitula may differ. Guggolz et al., (1968) reported that normal clean hull type varieties had low kernel percentage than the striped and thin hull type varieties. The kernel percentage varied from 50 to $62 \%$ (38 to $50 \%$ hull content) in normal clean hull type varieties and from 74 to $76 \%$ (24 to $26 \%$ hull content) in striped or thin hull type varieties.

Variation for hull thickness in safflower has been reported in different germplasm accessions. Baumler et al., (2006) reported that hull thickness of safflower seeds varied between 0.282-0.407 mm. Rahim et al., (2014) observed that hull thickness in 10 safflower varieties ranged from 0.315 to $0.397 \mathrm{~mm}$. A well-developed hull (achene) causes a reduction of oil content. It is suggested that thickness of hull should be less than $50 \%$ in safflower varieties (Dajue and 
Mundel, 1996), which could lead to reduction of the hull and increase in oil percentage. Safflower varieties with low hull thickness $(0.315 \mathrm{~mm})$ had higher oil content $(32.47 \%)$ compared to those with high hull thickness $(0.397 \mathrm{~mm})$, which had low oil content (29\%) (Rahim et al., 2014).

\section{Seed colour}

In safflower genotypes, five types of seed coat colours have been observed namely white, cream, brown, black and grey (IBPGR, 1983). However, only three types of seed colours (white, cream and brown) were observed among 61 safflower genotypes (Table 1). The numbers of genotypes with white, cream and brown seeds were 39, 20 and 2 respectively. The results suggest that white and cream colour seeds predominate in the safflower genotypes set studied.

The epidermis, hypodermis, parenchymous and endosperm layers are all very thin. These layers are divided by a thin layer of melanin and dark brown in colour. The two epidermal layers of the seed coat are also brown. Normal hull varieties have thick schlerenchyma layer that completely hide the melanin layer and appears bright white, which is generally preferred. A mutant line that carry pigmentless hull by eliminating melanin layer was also reported (Smith, 1996).

Seed coat colour is known to be associated with the oil content and meal quality in oilseed crops. It is reported that seed coat of Brassica genotypes contain biochemical compounds namely proanthocyanidins and tannins, which contribute for colour. These compounds are present in black or brown seeded genotypes and reduce the digestibility of seed meal for animal feeding. However, the yellow seeded genotypes have thinner and translucent seed coat which contributes for low hull content and big kernel and thus possess high oil or protein content (Rahman et $a l ., 2010)$. The yellow seeds have less tannins and less fibre compared to brown/black seeds thus possessing superior meal quality. However, the information on biochemical characterization of seed colour is not available in safflower. Interestingly, most of the normal hull seeds were white coloured and the striped hull seeds were cream coloured. This observation suggests the possibility of association between striped hull types with cream colour, which needs to be studied further. A possibility is that striped hull types have reduced hull content due to reduction in schlerenchymous layer, which would lead to appearance of cream colour with the mix of white and brown. Smith (1996) indicated that brown striped seed character of a high oil variety imparted an odour reminiscent of wet straw and black colour to the oil, which may be undesirable to the users.

\section{Bulk density $\left(\mathrm{t} / \mathrm{m}^{3}\right)$}

Bulk density values of the freshly harvested seeds of all checks were about 0.50 and it ranged from 0.40 to 0.64 with the mean of 0.50 (Table 1) in the germplasm. Highest bulk density was recorded in GMU-9 (0.64) and the lowest in EC-27 (0.40). Among the genotypes studied bulk density is an important physical seed quality parameter, which is useful for determining seed processing and storage requirements. It is of interest in breakage susceptibility and hardness studies. It is known to be influenced by the genotype, seed size, shape, moisture content and quality. Erica et al., (2004) reported the bulk density of safflower seeds in the range of $0.427-0.450 \mathrm{t} / \mathrm{m}^{3}$. Shakeri and Khodabakhshian (2011) reported that bulk density of two safflower varieties at different moisture levels ranged from $0.550-0.645$ and $0.535-0.630 \mathrm{t} / \mathrm{m}^{3}$, respectively. In general, the small seeds exhibited a higher bulk density 
than the large seeds because for small seeds the specific surface area of hull is lower than the larger seeds. Sun et al., (2014) reported that canola varieties differed significantly for bulk density, which decreased with increase in oil content. In this study, it was observed that high oil check variety Centennial (0.51) had comparatively lower bulk density than the low oil check varieties A1 (0.56) and Bhima (0.56).

\section{Frequency distribution}

The distribution of phenotypic values of seed morphological traits such as seed length, seed breadth, seed thickness, length breadth ratio, length breadth product, length breadth thickness product, hull content, test weight and bulk seed density clearly indicate quantitative nature of genetic variation showing continuous distribution across genotypes. The seed colour and hull type showed qualitative nature of variation with distinct groups within the genotypes set.

A frequency distribution provides a summarized grouping of data divided into mutually exclusive classes and the number of concurrences in a class. It is applied to indicate the nature of genetic variation (qualitative or quantitative) for traits in a population. When discrete phenotypic classes are found for a trait in the population, it is an indication of qualitative nature of variation and if the phenotypic data could not be grouped into discrete classes, it is an indication of quantitative nature of variation. In this study, for most of the seed morphological traits, except hull type and seed colour, continuous distribution was observed suggesting that those are genetically complex traits, which may be controlled by many genes and influenced by the environment. The traits that show qualitative variation is called simple traits and possibly controlled by a few genes. Genetic studies on hull types clearly indicate that they are simply inherited and a number of genes have been described: partial hull (par), thin hull (th), striped hull (stp), grey-striped hull (stp2) and reduced hull (rh) (Singh and Nimbkar, 2007).

\section{References}

Abel, G.H. 1976. Inheritance of stem length and its components in safflower. Crop Science.16: 374-376.

Applewhite, T.H. 1966. The composition of safflower seed. Journal of the American Oil Chemists Society. 43: 406-408.

Baumler, E., Cuniberti, A., Nolasco S.M and Riccobene, I.C. 2006. Moisture dependent physical and compression properties of safflower seed. Journal of Food Engineering. 72: 134-140.

Boothe, J., Nykiforuk, C.Y., Zaplachnski, S and Snarka, S. 2010. Seed based expression systems for plant molecular farming. Plant Biotechnology Journal. 8: 588-606.

Classen, C.E., Ekdahl, W.G and Severson, G.M. 1950. The estimation of oil percentage in safflower seed and the association of oil percentage with hull and nitrogen percentages, seed size and degree of spininess of the plant. Agronomy Journal. 42: 478-482.

Dajue, L and Mundel, H.H. 1996. Safflower (Carthamus tinctorius L.). IPGRI, Rome, Italy. pp. 83.

Dajue, L and Mundel, H.H. 1996. Safflower, Carthamus tinctorius L., promoting the conservation and use of under-utilized and neglected crops. Institute of Plant Genetics and Crop Plant Research, Gatersleben. International Plant Genetic Resources Institute, Rome, Italy.

Deshpande, S.D., Bal, S and Ojha, T.P. 1993. Physical properties of soybean. Journal of Agricultural Engineering Research. 56: 89-98. 
Duthion, C and Pigeaire, A. 1991. Seed lengths corresponding to the final stage in seed abortion of three grain legumes. Crop Science. 31: 1579-1583.

Ebert, W.W and Knowles, P. F. 1968. Development and anatomical characteristics of their hull mutants of Carthamus tinctorius (compositae). American Journal of Botany. 55: 421430.

Ebert, W.W and Knowles, P.F. 1966. Inheritance of pericarp types, sterility and dwarfness in several safflower crosses. Crop Science. 6: 579-582.

Erica, B., Cuniberti, A and Susana, M. 2004. Moisture dependent physical and compression properties of safflower seed. Journal of Food Engineering. 2: 134-140.

FAOSTAT. 2012. Food and Agriculture Organization, Rome, Italy (http://faostat.fao.org).

Fernandez-Martinez, J.M., Rio, M and Haro, A. 1993. Survey of safflower (Carthamus tinctorius L.) germplasm for variants in fatty acid composition and other seed characters. Euphytica. 69: 115-122.

Guggolz, J., Rubis, D.D., Herring, V.V., Palter, R and Kohler, G.O. 1968. Composition of several types of Safflower seed. Journal of the American Oil Chemists Society. 45: 689-693.

Hartwig, E. E and Collins, F.I. 1962. Evaluation of density classification as a selection technique in breeding soybeans for protein or oil. Crop Science. 2: 159-162.

IBPGR. 1983. Descriptors of safflower. International Board for Plant Genetic Resources. AGPG: IBPGR, Rome, Italy. 81: 93.

Li, D and Mundel, H.H. 1996. Safflower. Carthamus tinctorius L. Promoting the conservation and use of underutilized and neglected crops. Institute of Plant
Genetics and Crop Plant Research, Gatersleben/International Plant Genetic Resources Institute, Rome, Italy.

Li, D and Mundel, H.H. 1996. Safflower. Carthamus tinctorius L. Promoting the conservation and use of underutilized and neglected crops. Institute of Plant Genetics and Crop Plant Research, Gatersleben/International Plant Genetic Resources Institute, Rome, Italy.

Li, N., Shi, W.P.J., Wang, X., Liu, G and Wang, H. 2015. The natural variation of seed weight is mainly controlled by maternal genotype in rapeseed (Brassica napus L.). PLoS ONE. 10 (4): 1-14.

Lockwood, T.E. 1966. A comparative anatomical study on the effects of mutant genes on the pericarp and seed coat of safflower (Carthamus tinctorius L.). Master's Thesis. University of Arizona.

Mukta, N. 2008. Safflower genetic resources in India-an overview. In Knights SE and Potter TD (Eds) Safflower Unexploited potential and world adaptability. Proceedings of the $7^{\text {th }}$ International Safflower Conference, Wagga Wagga, New South Wales, Australia.

Mukta, N., Praveen Reddy, A., Lavanya, C and Dudhe, M.Y. 2012. Variability for DUS characteristics in released varieties of safflower (Carthamus tinctorious L.) in India. Journal of Oilseeds Research. 29 (Special issue). 133-135.

Olasoji, J.O.S.R., Ankande and Owolade, O.F. 2011. Genetic variability in seed quality of African yam beans (Sphenostylis stenocarpa). African Journal of Agricultural Research. 6 (27): 5848-5853.

Rahim, A.D.A. 2014. Dimension, geometric, agricultural and quality characteristics of safflower seeds. Turkish Journal of Field Crops. 19: 7-12. 
Rahman, M., Peter, B.E and McVetty. 2010. A review of Brassica seed color. Canadian Journal of Plant Science. 91: 437-446. doi:10.4141/CJPS10124.

Rudolphi, S., Becker, H.C., Schierholt, A and Ehbrecht, S.V.W. 2012. Improved estimation of oil, linoleic and oleic acid and seed hull fractions in safflower by NIRS. Journal of American Oil Chemists Society. 2012. 89: 363-369. doi 10.1007/s11746-011-1920-y.

Shakeri, Khodabakshian, R., Emadi, B and Abbaspur, F.M.H. 2011. Some engineering properties of sunflower seed and its kernel. Journal of Agricultural Science and Technology. 4: 37-46.

Singh, V and Nimbkar, N. 2007. Safflower In: Genetic resources, chromosome engineering and crop improvement: oilseed crops. Singh, R.J (ed), CRC Press. 167-194.

Smith, J.R. 1996. Safflower. AOCS Press, USA. 615-616.

Sun, Fuji Jian, Digvir S., Jayas, Noel, D.G., White and Paul, G. 2014. Physical properties of three varieties of high oil canola and one variety of low oil canola. Transactions of the American Society of Agricultural and Biological Engineers. 57 (2): 599-608.

Urie, A.L and Zimmer, D.E. 1970. A reducedhull seed character of safflower. Crop Science. 10: 371-372.

Urie, A.L. 1986. Inheritance of partial hull in safflower. Crop Science. 26: 493-498.

\section{How to cite this article:}

Kartoori Saisanthosh, K. Keshavulu, T. Joesph Raju, Kadirvel Palchamy, N. Mukta and Razia Sultana. 2018. Variability Studies for Seed Morphological Traits in Safflower Genotypes. Int.J.Curr.Microbiol.App.Sci. 7(10): 2204-2216. doi: https://doi.org/10.20546/ijcmas.2018.710.253 